\title{
EVALUASI KEBIJAKAN \\ PERCEPATAN PENANGGULANGAN KEMISKINAN DI KABUPATEN SUBANG
}

\author{
Oleh: \\ Nuraida*, Budiman Rusli, Sintaningrum, Mudiyati Rahmatunnisa \\ *Email : nuraida_74@yahoo.co.id \\ Program Doktor Administrasi Publik Fakultas Ilmu Sosial dan Ilmu Politik \\ Universitas Padjajaran Bandung
}

\begin{abstract}
ABSTRAK
Kemiskinan merupakan masalah yang banyak terjadi hampir diseluruh wilayah Indonesia, tanpa terkecuali di Kabupaten Subang. Kemiskinan di wilayah ini masih cukup tinggi sekalipun banyak program penanggulangan kemiskinan telah dilakukan. Untuk itu, maka penelitian ini difokuskan pada Evaluasi Kebijakan Percepatan Penanggulangan Kemiskinan di Kabupaten Subang, mengingat program-program yang ada hanya dinikmati tidak lebih dari 20 persen penduduk miskin yang ada. Metode yang dipakai dalam penelitian ini adalah metode kualitatif. Adapun sumber data diperoleh dari sumber data primer dan sekunder. Dengan teknik pengumpulan data dilakukan melalui studi lapangan dan studi pustaka,dengan wawancara langsung, observasi, forum group discussion (FGD), dan studi kepustakaan. Informan dalam penelitian ini berasal dari Kementrian Sosial, Bappeda Jawa Barat, unsur pemerintah daerah, tim TKPKD, unsur perguruan tinggi dan masyarakat sebagai kelompok penerima manfaat. Hasil penelitian menunjukkan bahwa dari sisi efektivitas mulai dari pembangunan system, mekanisme penyaluran sampai kepada sumber daya finansial maupun sumberdaya manusia belum optimal. Begitupun untuk efisiensi. Pemanfaatan sumberdaya yang ada juga belum maksimal. Responsivitas rendah, karena rentang kendali dan kontrol lemah. Perataan juga belum terdistribusi dengan baik, sehingga ketepatan sasaran bagi rumah tangga miskin belum mencapai sasaran yang ditetapkan dalam program-program percepatan. Dari hasil evaluasi kinerja yang menjadi hambatan utama di Kabupaten Subang adalah otorisasi atau kewenangan, disusul kemudian efisiensi dan efektivitas, disiplin dan inisiatif. Bahwa jika dilihat dari dampak Kebijakan Percepatan Penanggulangan Kemiskinan terhadap kelompok penerima manfaat di Kabupaten Subang, tidak berdampak cukup besar bagi perubahan kehidupan mereka.
\end{abstract}

Kata Kunci : Evaluasi, Kebijakan Percepatan Penanggulangan Kemiskinan 
MIMBAR

JURNAL PENELITIAN SOSIAL DAN POLITIK Juni 2019 ISSN : 2252-5270 \& E-ISSN : 2620-6056

\section{A. Pendahuluan}

Masalah kemiskinan merupakan masalah yang muncul di setiap negara di dunia, terutama di negara-negara berkembang. Masalah ini menyangkut eksistensi dari hak untuk mendapatkan kehidupan yang layak, sebagai hak dasar manusia. Isu kemiskinan ini menjadi salah satu isu yang mendapatkan perhatian negara-negara di dunia. Deklarasi MDGs merupakan hasil perjuangan dan kesepakatan bersama antara negara-negara berkembang dan maju. Negara-negara berkembang berkewajiban untuk melaksanakannya. Sedangkan negaranegara maju berkewajiban mendukung dan memberikan bantuan terhadap upaya keberhasilan setiap tujuan dan target MDGs

(Sumber:

http.www.undp.org;2017)

Salah satu targetnya adalah mengurangi jumlah penduduk miskin hingga $50 \%$ di tahun 2015. Kedelapan tujuan pembangunan millenium, yakni menanggulangi kemiskinan dan kelaparan, mencapai pendidikan dasar untuk semua, mendorong kesetaraan gender dan pemberdayaan perempuan, menurunkan angka kematian anak, meningkatkan kesehatan ibu, memerangi HIV/AIDS, malaria, dan penyakit menular lainnya, memastikan kelestarian lingkungan hidup, mengembangkan kemitraan global untuk pembangunan

(http://www.un.org/millennium/declaratio n/ares552e.hal1 pdf, 3 maret 2018).

Sebagai kelanjutan dari MDGs, maka kemudian disepekatilah Sustainable Development Goals (SDGs). Sebanyak 17 tujuan pembangunan berkelanjutan SDGs dan 169 target melengkapi apa yang belum tercapai di MDGs dilanjutkan. Salah satu goal dari SDGs adalah mengakhiri kemiskinan dalam segala bentuk dan dimensinya pada 2030(http://sustainabledevelopment.un.org /sdgs/2016).

Pemerintah Indonesia telah membuat kesepakatan tersebut menjadi komitmen nasional sesuai Undang Undang Dasar (UUD) 1945, pasal 34 (1) dan (2), pemerintah mengatur hal tersebut yang dituangkan dalam Undang-Undang Nomor 11 Tahun 2009 tentang Kesejahteraan Sosial. Guna pemenuhan kebutuhan dasar itulah kemudian pemerintah mengeluarkan Peraturan Presiden (Perpres) RI Nomor 13 Tahun 2009 tentang Koordinasi Penanggulangan Kemiskinan. Dalam bagian pertama Perpres ini menyebutkan bahwa penanggulangan kemiskinan adalah kebijakan dan program pemerintah dan pemerintah daerah yang dilakukan secara sistematis, terencana, dan bersinergi dengan dunia usaha dan masyarakat untuk mengurangi jumlah penduduk miskin dalam rangka meningkatkan derajat kesejahteraan rakyat. Pada perkembangan berikutnya, sebagai pengganti Perpres 13 tahun 2009 tentang Koordinasi Penanggulangan Kemiskinan, Pemerintah kemudian mengeluarkan Peraturan Presiden Perpres Nomor 15 Tahun 2010 tentang Percepatan Penanggulangan Kemiskinan yang mengatur tentang Arah Kebijakan, Strategi dan Program Percepatan Penanggulangan Kemiskinan dan Tim Nasional Percepatan Penanggulangan Kemiskinan Serta Hubungan Kerja dan Tata Kerja Tim. Yang kemudian diperkuat melalui Peraturan Mentri Dalam Negeri Nomor 42 Tahun 2010 tentang Tim Koordinasi Penanggulangan Kemiskinan Provinsi dan Kabupaten/Kota. Regulasi tentang pemenuhan kebutuhan hak dasar yang harus dinikmati masyarakat, terutama ditujukan bagi masyarakat miskin kemudian diatur dengan Undang-Undang Nomor 13 Tahun 2011 tentang Penanganan Fakir Miskin.

Penelitian yang dilakukan peneliti berkaitan dengan Kebijakan Percepatan Penanggulangan Kemiskinan. Apakah pemberian ketiga program dalam percepatan itu sudah dapat memenuhi tujuanya membantu masyarakat miskin untuk keluar dari lingkaran kemiskinan atau tidak. Maka dari itu, riset ini mengarahkan pada fokus evaluasi yang dilakukan untuk mengetahui sejauhmana keberhasilan ketercapaian programprogram dimaksud. Secara umum kemiskinan diartikan sebagai kurangnya pendapatan untuk memenuhi kebutuhan hidup pokok atau dasar. Mereka yang dikatakan miskin adalah yang memiliki pengeluaran per hari sebesar US\$ 2 Selain itu, Bank Dunia menetapkan klasifikasi 
MIMBAR

JURNAL PENELITIAN SOSIAL DAN POLITIK

Juni 2019 ISSN : 2252-5270 \& E-ISSN : 2620-6056

Volume 8 No. 1

sangat miskin (extreme poor) untuk yang pengeluaran per harinya di bawah US\$ 1 (Khomsan, 2015:18).

Penduduk Kabupaten Subang adalah 1.560.293. Dari data tersebut jumlah penduduk miskinnya sesuai Basis Data Terpadu (BDT) adalah sejumlah 644.496 jiwa atau sejumlah 41,3\%. Berdasarkan data tersebut, jelas terlihat bahwa jumlah penduduk miskin di Kabupaten Subang masih tinggi. Kebijakan Percepatan Penanggulangan Kemiskinan belum menjadi solusi bagi pengurangan angka kemiskinan yang ada di wilayah ini, namun dalam kenyataannya tidaklah berjalan sebagaimana tujuan yang ingin dicapai dalam program. Dari data yang ada, kondisinya berbanding terbalik dengan tujuan percepatan dimana target pengurangan jumlah penduduk miskin harus berada diatas 50\% di tahun 2015 dan berkurang di tahun 2023 sampai tidak ditemukan lagi penduduk miskin di wilayah Kabupaten Subang, capaiannya masih rendah hanya $8,7 \%$. Jika dilihat dari capaian tersebut diatas, efektivitas program yang ada masih rendah.

Berdasarkan hasil pemaparan di atas, dari penjajakan yang peneliti lakukan, peneliti mengidentifikasi masalah sebagai berikut: bahwa kinerja kebijakan percepatan penanggulangan kemiskinan di Kabupaten Subang belum optimal mencapai target yang diinginkan. Maka terkait dengan fakta-fakta tersebut di atas, kebijakan percepatan penanggulangan kemiskinan di Kabupaten Subang layak dijadikan sebagai sasaran dari objek program yang harus di evaluasi. Pemilihan tema riset ini didasarkan pada beberapa tinjauan hasil penelitian sebelumnya yang relevan dengan penelitian ini. Hal tersebut dapat dilihat dari beberapa penelitian tentang pelaksanaan Kebijakan Penanggulangan Kemiskinan, yang tidak hanya dilakukan di Indonesia, namun dilakukan juga oleh negara lain, terutama negara under developing countries. Hasil penelitian sebelumnya menunjukkan bahwa persoalan kemiskinan menjadi masalah penting hampir di semua negara di dunia. Ada banyak riset tentang kebijakan penanggulangan kemiskinan namun dalam prosesnya tidak berlangsung secara ideal, mulai dari implementor, prosedur, maupun target sasaran. Selain itu, eksternal faktor juga menjadi banyak penyebab kurang optimalnya keberhasilan penanggulangan kemiskinan. Beberapa hasil riset di Indonesia sendiri terkait dengan lambatnya program penanggulangan kemiskinan lebih diakibatkan karena penanganan program yang bersifat parsial. Dalam percepatan penanggulangan kemiskinan ketidak optimalan capaian hasil lebih banyak diakibatkan oleh penanganan program yang tidak terintegrasi satu sama lain.

\section{B. Metode Penelitian}

Berdasarkan latar belakang, masalah dan tujuan penelitian ini maka menurut peneliti yang sesuai dengan metode penelitian ini adalah menggunakan jenis penelitian kualitatif dengan analisis deskriptif. Penelitian kualitatif dipergunakan untuk mengetahui apakah Kebijakan Percepatan Penanggulangan Kemiskinan yang dilakukan di Kabupaten Subang sudah mencapai tujuan yang diharapkan atau tidak. Pendekatan kualitatif dicirikan oleh tujuan penelitian yang berupaya memahami gejalagejala yang tidak memerlukan kuantifikasi atau gejala-gejala tersebut tidak mungkin diukur secara tepat seperti yang dipergunakan dalam penelitian kuantitatif. Namun demikian, untuk menjelaskan penelitian evaluasi tentu saja sebenarnya harus menggunakan ukuran keberhasilan, namun penelitian kali ini hanya menggambarkan faktor yang menggambarkan kondisi yang mempertanyakan apakah Kebijakan Percepatan Penanggulangan Kemiskinan berjalan sesuai dengan tujuan yang diharapkan ataukah tidak dan bagaimana dampaknya terhadap kelompok penerima manfaat.

\section{Hasil Penelitin}

Program Percepatan Penanggulangan Kemiskinan sudah sejak lama berlangsung. Untuk mengetahui sampai seberapa jauh program percepatan ini berdampak kepada keluarga miskin, maka perlu dilakukan evaluasi. Maka dari itu, peneliti tertarik untuk melakukan evaluasi terhadap program ini. Teori yang dipakai oleh peneliti dalam penelitian ini adalah ukuran efektivitas dari Dunn, maka hasil penelitian evaluasi kebijakan percepatan 
penanggulangan kemiskinan di Kabupaten Subang terbagi dalam beberapa ulasan sebagai berikut :

\section{Kinerja \\ Kebijakan \\ Percepatan}

\section{Penanggulangan Kemiskinan}

1. Efektivitas

Efektivitas dalam kegiatan organisasi dapat dirumuskan sebagai tingkat pencapaian sasaran kegiatan atas target yang telah ditentukan. Sedangkan organisasi dipandang efektif apabila mampu mencapai seluruh target yang telah ditentukan. Dalam hal ini, kebijaksanaan dan praktek manejemen dalam Program Percepatan Penanggulangan Kemiskinan di Kabupaten Subang lebih di dominasi oleh sikap pelaksana di lapangan, terutama dalam hal penentuan kelompok sasaran yang menjadi ujung tombak program ini. Kondisi ini tentu saja akan memberi kontribusi penting bagi ketercapaian sasaran program untuk secara simultan diharapkan mampu keluar dari lingkaran kemiskinan. Dengan demikian dapat disimpulkan bahwa keberadaan organisasi sebagai motor utama program terbukti memiliki kesesuaian dengan konsep steers yang mengemukakan bahwa efektivitas organisasi dapat diukur dari penilaian pihak luar.

Dalam penelitian menyangkut Kebijakan Percepatan Penanggulangan Kemiskinan ini eksistensi organisasi penyelenggara menjadi kunci utama pengendalian program, mulai dari tingkat hulu hingga hilir. Maka keberhasilanya akan sangat banyak ditentukan oleh pemerintah, karena masyarakat hanya bersifat sebagai objek penerima manfaat saja, yang secara pasif tentu tidak akan mampu berbuat banyak berkontribusi terhadap kesuksesan Program Percepatan Penanggulangan Kemsikinan di Kabupaten Subang

\section{Efisiensi}

$$
\text { Program Percepatan }
$$

Penanggulangan Kemiskinan adalah pelayanan Kartu Indonesia Sehat, masyarakat miskin mendapatkan pelayanan kesehatan yang dibiayai dari BPJS. Berdasarkan beberapa temuan di atas, dapat disimpulkan bahwa pemanfaatan SDM dalam Program Percepatan Penanggulangan Kemiskinan di Kabupaten Subang belum efisien. Ini dapat dilihat dari penggunaan SDM pendamping untuk keluarga penerima manfaat Kartu
Indonesia Sejahtera maupun pendataan untuk Program Indonesia Sehat yang berbeda. Pelaksana yang tidak sama ini dalam pelaksanaannya dapat menimbulkan tumpang tindih data dan informasi Keluarga penerima manfaat untuk semua jenis Program Percepatan Penanggulangan Kemiskinan di Kabupaten Subang. Selain itu, akan kesulitan dalam menetapkan pengendalian, karena sumber daya yang ada tidak ada dalam lini dan komando formal Program Percepatan Penanggulangan Kemiskinan di Kabupaten Subang. Selain itu, pola distribusi dan strategi pembayaran pada tataran pelaksana teknis berbeda. Ini menimbulkan persoalan baru ditataran teknis. Seperti diketahui bahwa untuk pendistribusian bantuan bagi KPM disetiap desa idealnya hanya dilakukan oleh dua warung mitra BRI link, namun pada kenyataannya di setiap desa terdapat 4 warung yang menyediakan untuk itu. Dan pemilihan warung yang ditunjuk untuk pendistribusian tidak dapat ditentukan, dengan kata lain KPM bebas memilih tempat pertukaran bahan makanan.

Keberadaan dari warungwarung tersebut saling berkompetisi. Tidak ada regulasi yang sama untuk mengatur besaran harga yang ditentukan bagi setiap program bantuan dalam bentuk beras. Betapa pentingnya peranan distribusi dalam menjaga kestabilan harga, karena kelemahan pengaturan harga dapat berefek negatif bagi pemberian bantuan yang diperuntukkan bagi KPM Program Percepatan Penanggulangan Kemiskinan di Kabupaten Subang, khususnya keluarga penerima manfaat untuk Program Indonesia Sejahtera

\section{Kecukupan}

Dilihat dari besaran bantuan, diakui beberapa KPM masih kurang memadai. Menurut mereka, yang besar itu bukan untuk iuran ini dan itu di sekolah. Akan tetapi untuk ongkos dan saku anak-anak. Sekalipun demikian, tetap disyukuri, karena masih ada perhatian pemerintah bagi pendidikan 
MIMBAR

JURNAL PENELITIAN SOSIAL DAN POLITIK

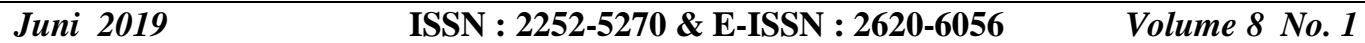

warga negaranya.

Berdasarkan hal tersebut terlihat bahwa sisa penggunaan dana BOS tidak dapat dikendalikan. Untuk penggunaan kelanjutannya itu menjadi kewenangan masing-masing KPM. Untuk penyaluran dana BOS untuk jenjang SLTP, ada informan yang menyebutkan bahwa dana BOS disimpan di sekolah, untuk kemudian dipakai bagi kepentingan pendidikan anak-anak. Ketika bantuan ini pun disimpan di sekolah tidak ada kontrol bagi penggunaannya, KPM tidak tahu menahu saldo yang ada. Tidak jarang bantuan yang ada tahu-tahu sudah habis. Ini menunjukkan bahwa fungsi kontrol terhadap pola penyaluran bantuan juga lemah.

Pada akhirnya, sampailah pada taraf kesimpulan bahwa penyaluran bantuan salah satu Program Percepatan Penanggulangan Kemiskinan di Kabupaten Subang belum memenuhi unsur kecukupan, dimana metode yang digunakan belum mampu membantu masyarakat miskin untuk bersekolah. Hal ini diperkuat oleh kondisi dimana, angka partisipasi sekolah hanya $6+1$, artinya rata-rata pendidikan di Kabupaten Subang hanya sampai kelas 1 SLTP.

\section{Pemerataan}

Hasil penelitian dari sisi perataan Kebijakan Percepatan Penanggulangan Kemiskinan di Kabupaten Subang belum memenuhi unsur pemerataan. Hal ini terlihat bahwa skema pemberian bantuan yang diberikan pemerintah belum mencerminkan pemerataan bagi kelompok lainnya. Sifat dari pemberian bantuan yang dibuat ternyata belum mengakomodir kelompok miskin lainnya, yang bukan dilihat dari miskin secara materil, akan tetapi lebih penting adalah, mengeluarkan KPM dari lingkaran kemiskinan yang sesungguhnya, dan memfasilitasi mereka untuk dapat mempermudah mengakses ke sumber ekonomi produktif.

Berdasarkan hasil penelitian peneliti, jelas terlihat bahwa pemerataan program ini belum terlihat. Bahwa seyogyanya program harus juga diberikan kepada para kepala rumah tangga untuk bisa berdikari. Exit program dimaksud tentu saja harus juga bersinergi dengan pendataan dari Program Percepatan Penanggulangan Kemiskinan di Kabupaten Subang. Selama ini, program ekonomi produktif terpisah tidak terkoneksi langsung dengan pemegang Kartu Indonesia Sehat, Indonesia Pintar maupun Indonesia Sejahtera.

\section{Responsivitas}

Dunn (2003; 437) mengemukakan bahwa kriteria responsivitas adalah penting karena analisis yang dapat memuaskan semua kriteria lainya (efektivitas, efisiensi, kecukupan, kesamaan) masih gagal jika belum menanggapi kebutuhan aktual dari kelompok yang semestinya diuntungkan dari adanya suatu kebijakan. Oleh karena itu, kriteria responsivitas cerminan nyata kebutuhan preferensi, dan nilai dari kelompokkelompok tertentu terhadap kriteria efektivitas, efisiensi, kecukupan dan kesamaan.

Responsivitas dalam penelitian ini juga menunjukkan kelemahan dari pelaksanaan Program Percepatan Penanggulangan Kemiskinan di Kabupaten Subang, Hal ini terlihat dari banyak aduan dari $\mathrm{kpm}$ yang tidak mendapatkan feed back dari implementor kebijakan, baik di tataran pengambilan kebijakan maupun di tataran teknis. Ketiadaan saluran penyampaian aspirasi menyebabkan fungsi dari aspirasi mandek. Hal ini tentu tidak akan memberi solusi bagi KPM untuk menyelesaikan berbagai persoalan yang terjadi di lapangan. Selain itu, pemerintah juga tidak akan dapat melakukan evaluasi yang pada akhirnya akan memperbaiki keadaan dari Program-Program dimaksud. Sebenarnya berbagai masukan itu sangat baik dan dapat dijadikan sebagai input bagi perbaikan program ke depan.

Saluran komunikasi menjadi saluran penting bagi harmonisasi ketercapaian program untuk mencapai sasaran yang diinginkan. Menurut beberapa informan yang dapat disimpulkan dari penelitian ini adalah bahwa Kebijakan Percepatan Penanggulangan Kemiskinan yang bersifat charity ini tidak mendidik masyarakat. Dengan demikian dapat disimpulkan bahwa responsivitas pemerintah untuk Kebijakan Percepatan Penanggulangan Kemiskinan masih rendah. Hal ini dikarenakan tidak berjalanya saluran komunikasi yang baik di antara pemerintah dengan $\mathrm{kpm}$ yang ada. Proses koordinasi lintas sektor, antar dinas terkait kemiskinan, kerapkali tidak dilaksanakan dengan baik. Pertemuan yang sedikitnya harus dilaksanakan per 3 bulan, hanya diselenggaran satu-dua tahun sekali. Sosialisasi terhadap KPM 
MIMBAR

JURNAL PENELITIAN SOSIAL DAN POLITIK

Juni 2019 ISSN : 2252-5270 \& E-ISSN : 2620-6056

Volume 8 No. 1

juga masih minim. Hal ini yang menyebabkan masyarakat lambat memahi perubahan kebijakan yang ada dalam percepatan penanggulangan kemiskinan di Kabupaten Subang.

Saluran komunikasi yang ada belum tersedia secara langsung. Keberadaan saluran komunikasi yang ada masih bersifat formal. Model penyampaian informasi sebagai input belum dapat dioptimalkan dalam rangka memperbaiki kinerja Program Percepatan Penanggulangan Kemiskinan di Kabupaten Subang.

\section{Ketepatan}

Ketepatan dapat diisi oleh indikator keberhasilan kebijakan lainnya (bila ada). Misalnya dampak lain yang tidak mampu diprediksi sebelumnya baik dampak tak terduga secara positif maupun negatif atau dimungkinkan alternatif lain yang dirasakan lebih baik. Berdasarkan hasil penelitian diperoleh bahwa ketepatan sasaran bagi KPM sedikitnya mampu memberi manfaat. Hanya saja pemerintah perlu membuat skenario secara berkesinambungan berkaitan dengan Kebijakan Percepatan Penanggulangan Kemiskinan. Masyarakat harus dibuat untuk dapat mandiri dan berdikari.

Berdasarkan hal tersebut di atas, perlu dibuat keberlangsungan program yang terkoneksi antara satu dengan yang lainnya. Kebijakan penanggulangan kemiskinan diharapkan tidak bersifat parsial. Integrasi program akan memudahkan untuk melakukan upaya dalam bentuk kontrol yang terpusat. Sinergitas antar pelaksana program juga sangat diperlukan.

Bukan jamannya lagi persoalan kompleks ditangani oleh satu institusi, akan tetapi pelibatan multi pihak dan multi aspek sangat dimungkinkan untuk mempercepat keberhasilan Kebijakan Percepatan Penanggulangan Kemiskinan. Selain itu, bagi pola bantuan yang sifatnya charity ini, perlu dibatasi masanya. Akan tidak baik apabila masyarakat menerima selama 15 tahun program ini secara terus menerus, akan tetapi mereka tetap berada di posisi yang sama dengan sebelumnya. Dengan demikian dapat disimpulkan bahwa Program Percepatan Penanggulangan Kemiskinan belum dapat mencapai tujuan yang diinginkan.

Dampak Evaluasi Kinerja Kebijakan Percepatan Penanggulangan Kemiskinan Policy Impact, Evaluation, and Change evaluasi kebijakan digunakan untuk mengidentifikasi berbagai faktor yang memberikan kontribusi kepada keberhasilan ataupun kegagalan dari suatu kebijakan. Output biasanya dapat dengan mudah dihitung, dijumlah, dan dianalisis secara statistik. Policy outcomes (seringkali disebut hasil), sebaliknya merupakan konsekuensi terhadap masyarakat, yang mau tidak mau, juga yang berasal dari tindakan pemerintah secara langsung atau tidak langsung.

Para peneliti kebijakan ingin tahu apakah kebijakan merupakan tujuan yang ingin dicapai. Dampak kebijakan campuran dari output dan outcome memiliki beberapa dimensi, yang kesemuanya harus diperhitungkan, melakukan evaluasi formal maupun dalam proses informal, yaitu kebijakan dapat mempengaruhi situasi atau kelompok disebut dengan third - party effects, spillover effects, atau eksternalitas. kebijakan memiliki beberapa konsekuensi terhadap masa depan berbagai kebijakan berdampak pada masalah publik secara langsung kebijakan memiliki manfaat positif, tetapi juga memerlukan biaya Efek dari kebijakan dan program dapat saja secara material (dapat dihitung / tangibel) atau simbolik (intangible).

Evaluasi kebijakan sebagai suatu aktifitas fungsional yang usianya sama dengan kebijakan itu sendiri. Evaluasi yang sistematis mencari informasi pada dampak suatu kebijakan atau program pada kebutuhan publik atau pun masalah secara langsung. Tiga desain evaluasi dibahas disini, yaitu experimental design, quasi experimental design, dan before and after study sebagai dasarnya. Experimental design merupakan metode klasik untuk mengevaluasi suatu kebijakan atau program. Pretests dan posttest dari dua kelompok digunakan untuk mengetahui perubahan before and after study, suatu program perbandingan hasil setelah suatu periode pelaksanaan implementasi terhadap waktu awal sebelum program dilaksanakan.

Dari hasil riset ini diperoleh kesimpulan bahwa kebijakan percepatan penanggulangan kemiskinan di Kabupaten Subang yang mana terdiri dari beberapa program, ternyata tidak berdampak secara langsung kepada kehidupan kelompok penerima manfaat. Bila dilihat dari sesudah maupun sebelum mendapatkan berbagai bantuan mayoritas kelompok penerima manfaat masih berada pada kondisi yang 
sama. Bahwa yang diperlukan oleh kelompok penerima manfaat sebenarnya adalah bagaimana mereka bisa produktif dan dapat keluar dari lingkaran kemiskinan, demi keberlangsungan masa depan yang lebih baik bagi keberlanjutan generasinya. Dampak dimaksudkan tentu dapat dibedakan menjadi dua, yaitu dampak positif dan dampak negatif. Menurut peneliti jika dampak positifnya lebih sedikit daripada dampak negatifnya, dan dalam kebijakan percepatan penanggulangan kemiskinan kebijakan yang dibuat tidak merubah apapun, maka sebaiknya kebijakan yang bersifat charity ini sedikit demi sedikit harus dikurangi dan dihentikan. Mengingat dampak negatif yang dirasakan jauh lebih besar, misalnya malah menumbuhkan sikap malas dan tidak mandiri.

\section{Kesimpulan dan Saran}

\section{Kesimpulan}

Berdasarkan hasil penelitian dapat disimpulkan bahwa: Kebijakan Percepatan Penanggulangan Kemiskinan di Kabupaten Subang masih belum berjalan optimal. Hal ini dapat dilihat dari beberapa hal sebagai berikut: Bahwa dari sisi efektivitas Kebijakan Percepatan Penanggulangan Kemiskinan di Kabupaten Subang belum efektif. Dalam hal efisiensi mekanisme penyaluran bantuan terhadap keluarga penerima manfaat masih belum efisien. Terkait kecukupan belum memenuhi unsur kecukupan dilihat dari penggunaan metode terhadap masalah yang ada dengan tujuan yang ingin dicapai dalam Kebijakan Percepatan Penanggulangan Kemiskinan. Untuk pemerataan, belum terlihat adanya pemerataan Kebijakan Percepatan Penanggulangan Kemiskinan di Kabupaten Subang. Pemberian bantuan baru diperuntukan pada bantuan berbasis keluarga, akan tetapi bagi kepala keluarga tidak terdapat program khusus. Sehingga mereka tidak akan dapat keluar dari lingkaran kemiskinan selama tidak diberi kesempatan yang sama dengan kelompok masyarakat lainya. Dalam hal responsivitas Kebijakan Percepatan menunjukan tidak berfungsinya saluran komunikasi dan aspirasi antara pemerintah dengan kelompok penerima manfaat dalam Kebijakan Percepatan Penanggulangan Kemiskinan di Kabupaten Subang dengan optimal dari sisi kelembagaan, baik secara formal maupun non formal. Terakhir, bahwa dari sisi ketepatan, Program Percepatan Penanggulangan Kemiskinan tidak tepat sasaran sehingga pencapaian tujuan percepatan pengurangan jumlah penduduk miskin tidak terjadi. Hal ini dapat dilihat dari keberadaan program yang tidak terintegrasi satu dengan lainnya.

\section{Saran}

1) Efektivitas : Perlu dilakukan penguatan kelembagaan mulai dari hulu sampai hilir Program Percepatan Penanggulangan Kemiskinan di Kabupaten Subang.

2) Efisiensi : Perlu dibuat dan diterapkan SOP yang lebih baik agar Program Percepatan Penanggulangan Kemiskinan di Kabupaten Subang berjalan dengan baik.

3) Kecukupan: Perlu dilakukan upaya perbaikan metode yang disesuaikan dengan tujuan yang diharapkan dalam Program Percepatan Penanggulangan Kemiskinan di Kabupaten Subnang.

4) Pemerataan : Perlu dibuat exit program ekonomi produktif bagi kepala keluarga yang mendapatkan bantuan dalam Program Percepatan Penanggulangan Kesmikinan di Kabupaten Subang

5) Responsivitas : Perlu dibuat saluran komunikasi direct maupun indirect dalam Program Percepatan Penanggulangan Kemiskinan di Kabuoaten Subang.

6) Ketepatan : Perlu dilakukan pembuatan skema baru program yang terintegrasi satu dengan lainnya dalam Program Percepatan Penanggulangan Kemiskinan di Kabupaten Subang.

\section{DAFTAR PUSTAKA}

Anwar, A. 2016. Kebijaksanaan Desentraliasi Fiskal Suatu Kerangka Pemikiran Sebagai Salah Satu Aspek Penting Dalam Pelaksanaan Otonomi Daerah. Makalah disampaikan pada Simposium Nasional " Forum Mahasiswa Pascasarjana Indonesia" di Institut Pertanian Bogor 15-17 Pebruari 2001.

Ali, Faried. 2012. Studi Analisa Kebijakan. Konsep, Teori dan Aplikasi Sampel 
MIMBAR

JURNAL PENELITIAN SOSIAL DAN POLITIK

Juni $2019 \quad$ ISSN : 2252-5270 \& E-ISSN : 2620-6056 Volume 8 No. 1

Teknik Analisa Kebijakan Pemerintah. Bandung : Refika Aditama

Anderson, James E.1975. Public Policy Making. USA: . New York: Holt, Rinehart and Winston.

Anderson, James E, 1994. Public Policy Making - An Introduction (second edition), Texas A \& M University.

Adisasmita, Rahardjo. 2011. Pengelolaan Pendapatan dan Anggaran Daerah. Yang Menerbitkan Graha Ilmu : Yogyakarta.

BAPPENAS dan Pusat Pengkajian dan Pengembangan Perekonomian Rakyat. 1996. Menuju gerakan nasional penanggulangan kemiskinan, Kajian Bersama Pengembangan Kebijaksanaan. Jakarta: Bappenas dan P3R

Creswell, W John. 2012. Research Design, Pendekatan Kualitatif, Kuantitatif dan Mixsd. Yogyakarta: Pustaka Pelajar.

Dale, Reidar. 2004. Evaluating Develompment Programmes and Projects, edisi kedua. New Delhi: Sage Publications.

Dunn, William N. 2000/1998. Pengantar Analisis Kebijakan Publik. Edisi kedua ; Diterjemaahkan oleh Samodra Wibawa dkk. Yogyakarta : Gadjahmada University Press. (1998)

Dunn, N William. 2003. Pengantar Analisis Kebijakan Publik. 2003. Yogyakarta: Gajah Mada University Press.

Dye. Thomas. R. 1992/1975. Understanding Public Policy. Seventh Edition. Englewood Cliffs. New Jersey : Prentice Hall.

Dwiyanto, Agus, dkk. 2006. Reformasi Birokrasi Publik di Indonesia. Yogyakarta: Gadjah Mada University Press.

Gertler, Paul J. 2016. Impact Evaluation In Practice, Second Edition. Washington DC. World Bank.

Gedeian, Arthur.G. dkk. 1991. Organization Theory and Design. Jakarta: Universitas Terbuka.

Indiahono, Dwiyanto. 2009. Kebijakan Publik Berbasis Dynamic Policy Analysis. Yogyakarta: Gava Media.

Jones, Charles O. Public Policy. 1994. Jakarta: PT Raja Grafindo Persada

Jones, Charles O. 1994/1984. Pengantar Kebijakan Publik (Public Policy).
Diterjemahkan oleh Ricky Istamto. Jakarta : PT. Raja Galuh Persndo.

Jones, Charles O. 1984. Pengantar Kebijakan Publik (Public Policy). Diterjemahkan oleh Ricky Istamto. Jakarta; PT. Raja Galuh Persindo.

Khomsan, Ali, dkk. 2015. Indikator Kemiskinan dan Mengklasifikasi Orang Miskin. Jakarta: Yayasan Pustaka Obor Indonesia dan Fakultas Ekologi Manusia IPB.

Kusumanegara, 2010. Solahuddin. Model dan Aktor Dalam Proses Kebijakan Publik. Yogyakarta: Gava Media

Lestari, Sri. 2012. Bantuan Sosial di Indonesia, Sekarang dan Ke Depan. Bandung: Fokus Media.

Lester, James P and Joseph Stewart, Jr., 2000, PublicPolicy ; An Evolutionary Approach. Belmont, CA,: Wadsworth.

Lester, J.P and Stewart, P. 2000. Public Policy : an Evolutionary Approach. Australia : Wadsworth.

Maipita, Indra. 2014.Mengukur Kemiskinan dan Distribusi Pendapatan. Yogyakarta: UPP STIM YKPN.

Mardimin, Yohanes. 1996. Kritis Proses Pembangunan di Indonesia. Penerbit Kanisius. Yogyakarta.

Mustopadidjaja. AR., 2003., Manajemen Proses Kebijakan Publik ; Formulasi, Implementasi dan Evaluasi Kinerja., Jakarta : LAN-RI dan Duta Foundation.

Maruti, Sri Kusrini. 2013. Responsivitas Pelayanan Kantor Pertanahan Kota Salatiga. Pascasarjana UNS. Surakarta

Nugroho, Riant. 2009. Public Policy. Jakarta: PT Elex Media Komputindo Kelompok Gramedia.

Nugroho, Riant. 2009. Pengantar Analisis Kebijakan. Darwin. Yogyakarta; Gadjah Mada University Press.

Nugroho, Riant. (2011). Public Policy. Jakarta: PT. Elex Media Komputindo.

Ndraha, Taliziduhu, 2003. Kybernology. (Ilmu Pemerintahan) I. Jakarta : Rineka Cipta.

Payne, Malcolm. 1997. Modern Social Work Theory. Chicago: lyceum books, Inc.

Patton, Carl V and Sawicki, David.S. 1986. Basic Methos of Policy of Analysis and Planning. New York : Prentice Hall - Englewood Cliffs. 
MIMBAR

JURNAL PENELITIAN SOSIAL DAN POLITIK ISSN : 2252-5270 \& E-ISSN : 2620-6056

Parsons, 2005. Public Policy, Pengantar Teori dan Praktik Analisis Kebijakan. Dialihbahasakan oleh Triwibowo Budi Santoso. Jakarta : Kencana.

Rusli, Budiman. 2013. Kebijakan Publik, Membangun Pelayanan Publik Yang Responsif. Bandung: Hakim Publishing.

Rofiq, Aunur. 2014. Pertumbuhan Ekonomi dan Kemiskinan, Kebijakan dan Tantangan Masa Depan. Jakarta: Republika Penerbit.

Ripley,B. Randall dan A.Frangklin, Grace. 1982. Bureaucracy and Policy Implementation.

Steers, Richard M. (1985). Efektivitas Organisasi. Jakarta: Erlangga

Rist, C, Ray. 1995. Policy Evaluation. England: Edward Elgar Publishing Limited. 2017

Sedarmayanti. 1995. Sumber Daya Manusia dan Produktivitas Kerja. Bandung: Ilham Jaya.

Sutherland, J.W. 1987. Management Handbook for Public Administrators. New York: Van Nostrand Reinhold.

Sardjo, Sulastri. 2017. Implementasi Model Evaluasi Formatif Program Pembangunan

Suharto, Edi. 2009. Kemiskinan dan Perlindungan Sosial di Indonesia, Menggagas Model Jaminan Sosial Universal Bidang Kesehatan. Bandung: Alfabeta.

Sutrisno, Edy. 2007. Budaya Organisasi. Kencana. Jakarta.

Steers, Richard M. 1984. Efektivitas Organisasi: Kaidah Perilaku. Terj. Jamin. Bandung: Erlangga.

Soetomo. 2010. Strategi-strategi Pembangunan Masyarakat. Yogyakarta :Pustaka Pelajar.

Soemitro, Sutyastie. 2002. Kemiskinan dan Ketidakmerataan di Indonesia. Jakarta: Rineka Cipta.

Saefullah, Djaja. 2012. Pemikiran Kontemporer Administrasi Publik, Perspektif Manajemen Sumber Daya Manusia Dalam Era Desentralisasi. Bandung: Laboratorium Pengkajian Penelitian dan Pengembangan Administrasi Negara LP3AN FISIP UNPAD

Sardjo, Sulastri, dkk. 2017. Implementasi Model Evaluasi Formulatif Program
Pembangunan Sosial. Jakarta: Yayasan Pustaka Obor Indonesia.

Suryana, Effendy. 2004. Gotong Royong Gawe Bakti Urang Subang. Subang: Bagian Humas Setda Kab. Subang.

Thoha, Miftah. 2008. Ilmu Administrasi Publik Kontemporer. Jakarta: Prenada Media Group.

Tim BP4D dan Badan Statistik Kabupaten Subang. 2017. Analisis Pembangunan Sosial Kabupaten Subang. Subang: Badan Perencanaan Pembangunan Penelitian dan Pengembangan Daerah Kabupaten Subang - Badan Pusat Statistik Kabupaten Subang

The Liang Gie. 1979. Kamus Administrasi. Jakarta: Gunung Agung.

Winarno, Budi. 2014. Kebijakan Publik, Teori, Proses dan Studi Kasus. Yogyakarta: CAPS (Centerof Academic Publishing Service).

Wibawa Samodra, Yuyun Purbokusumo, dan Agus Pramusinto., 1994., Evaluasi Kebijakan Publik., Jakarta : RajaGrafindo Persada.

Widodo, Joko. 2008.Analisis Kebijakan Publik. Jakarta : Bayumedia.

Widodo, Djoko. 2001. Akuntabilitas Dan Kontrol Birokrasi. Surabaya: Insan Cendikia.

Zainal, Said. 2016. Kebijakan Publik. 2016.

JURNAL Jakarta: Salemba Humanika.

Darwis.V dan Nurmanaf.A.R, (2001), Pengentasan Kemiskinan : Upaya Yang Telah Dilakukan Dan Rencana Waktu Mendatang, FAE. Volume 19 No. 1 Juli $2001: 55-67.1$

Jurnal Administrasi Negara Vol 1 No 2, 2 Maret 2001. Supriyono. Responsivitas dan Akuntabilitas Sektor Publik. FIA. Malang.

Jurnal Sosiohumaniora, Vol. 7, No. 3, November 2005 : 220 233.Karnesih.E, (2005), Pengentasan Penduduk Miskin Sebagai Refleksi Pelaksanaan Otonomi Daerah Jawa Barat,

Jurnal Sosio Konsepsia dan Sosio Informa ejournal Kemensos RI. 2009. Evaluasi Penanggulangan Kemiskinan Melalui Program Pemberdayaan Fakir MiskinBantuan Langsung

Jurnal Pembangunan Wilayah dan Kota, 
Volume 9 (4): 343-354 Desember 2013.Ummami., 2013; Cara Pandang dan Upaya Pemerintah dalam Mengurangi Kemiskinan.

Jurnal Riptek Vol. 7, No. 1, Tahun 2013, Hal. 27-38.Kertati.I, (2013), Analisis Kemiskinan Kota Semarang berdasarkan Data Pendataan Program Perlindungan Sosial (PPLS).

Jurnal WigaVol 4. No1, Maret 2014. Isnan Murdiansyah. Evaluasi Pengentasan Kemiskinan Berbasis Pemberdayaan Masyarakat (Studi Kasus Pada Program Gerdu Taskin di Kabupaten Malang) ISSN 2088-0944

Jurnal Bisnis dan Manajemen 210, Vol. 4, No. 2, Agustus 2014, Yoghi Citra. Analisis Faktor-Faktor Yang Mempengaruhi Kemiskinan di Indonesia. UIN Syarif Hidayatullah Jakarta.

Jurnal PIRAMIDA Vol. X No. 1, Volume X No. 1 Juli 2014.Mahaeni.AAIN. et.al, (2014), Evaluasi Program -pr ogram Pengentasan Kemiskinan di Provinsi Bali.

Jurnal Teknik PWK Volume 3 Nomor 1 2014 Online : http://ejournals1.undip.ac.id.Natalia.M dan Alie.M.M, (2014), Kajian Kemiskinan Pesisir Di Kota Semarang (Studi Kasus: Kampung Nelayan Tambak Lorok).

Jurnal Kebijakan dan Manajemen Publik, UNAIR Vol 3, No 3, September Desember. 2015. Motic Devianto Novandric. Implementasi Kebijakan Percepatan Penanggulangan Kemiskinan (Strategi Percepatan Penanggulangan Kemiskinan Melalui Pelaksanaan Desa Model Di Kelurahan Mondokan, Kecamatan Tuban, Kabupaten Tuban.

Jurnal Kebijakan dan Manajemen Publik, ISSN $2303-341 X$. Volume 3, Nomor 3, September - Desember, 2015

Jurnal Ekonomi dan Kebijakan Publik Vol 6, No 2 (2015). Nafiah Ariyani, Akhmad Fauzi, Bambang Juanda, Irfan Syauqi Beik. Evaluasi Program Pengentasan Kemiskinan Menggunakan Metode Rapoverty.

Journal of Nonformal Eduacation, Vol. 1 No 1, Tahun 2015.Desmawati.L, Achmad Rifai RC.A dan
Mulyono.S.E, Penanggulangan Masyarakat Miskin Kota Rawan Kriminalitas Melalui Pemberdayaan Masyarakat Di Jalur Pendidikan Nonformal Di Kota Semarang,

Journal Educational Philosophy and

Theory. Incorporating. Xue Eryong.ISSN: 0013-18571. China

Jurnal Agribis - Fakultas Pertanian, Univ. Tulungagung. Vol 12, No 14 (2016). Roidah Syamsu. Evaluasi Kebijakan Pengentasan Kemiskinan Dalam Program Keluarga Harapan Di Kecamatan Rejotan Kabupaten Tulungagung.

Arabian Journal of Business and Management Review, Research Article, 2016, 6:6.AbaraWilliam. ISSN: 2223-5833. Nigeria

Jurnal Sosio Konsepsia dan Sosio Informa ejournal Kemensos RI. Vol 8, no 1 (2018). Suharyadi. Penanggulangan Kemiskinan Berbasis Keterpaduan Data Di Kota Semarang. 